Research Paper

\title{
Cultured Human Periosteal-Derived Cells Have Inducible Adipogenic Activity and Can Also Differentiate Into Osteoblasts in a Perioxisome Proliferator- Activated Receptor-Mediated Fashion
}

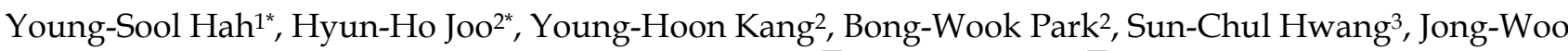 \\ Kim ${ }^{4}$, Iel-Yong Sung5, Gyu-Jin Rho6, Dong Kyun Woo ${ }^{7 凶}$, June-Ho Byun ${ }^{{ }^{\bowtie}}$ \\ 1. Clinical Research Institute of Gyeongsang National University Hospital, Jinju, Republic of Korea; \\ 2. Department of Oral and Maxillofacial Surgery, Institute of Health Sciences, Gyeongsang National University School of Medicine, Jinju, Republic \\ of Korea; \\ 3. Department of Orthopaedic Surgery, Institute of Health Sciences, Gyeongsang National University School of Medicine, Jinju, Republic of Korea; \\ 4. Department of Thoracic and Cardiovascular Surgery, Institute of Health Sciences, Gyeongsang National University School of Medicine, Jinju, \\ Republic of Korea; \\ 5. Department of Oral and Maxillofacial Surgery, College of Medicine, Ulsan University, Ulsan, Republic of Korea; \\ 6. OBS/Theriogenology and Biotechnology, College of Veterinary Medicine, Gyeongsang National University, Jinju, Republic of Korea; \\ 7. College of Pharmacy and Research Institute of Pharmaceutical Sciences, Gyeongsang National University, Jinju, Republic of Korea. \\ * These authors contributed equally to this work.
}

$\triangle$ Corresponding authors: June-Ho Byun (Department of Oral and Maxillofacial Surgery, Institute of Health Sciences, Biomedical center (BK21), 660-702, Gyeongsang National University School of Medicine, Jinju, Republic of Korea, Tel: 82-55-750-8258, Fax: 82-55-761-7024, E-mail: surbyun@gsnu.ac.kr) or Dong Kyun Woo (College of Pharmacy and Research Institute of Pharmaceutical Sciences, Gyeongsang National University, Jinju, Republic of Korea, Tel: 82-55-772-2428, E-mail: dongkyun.woo@gnu.ac.kr).

(c) Ivyspring International Publisher. This is an open-access article distributed under the terms of the Creative Commons License (http://creativecommons.org/ licenses/by-nc-nd/3.0/). Reproduction is permitted for personal, noncommercial use, provided that the article is in whole, unmodified, and properly cited.

Received: 2014.05.09; Accepted: 20 14.08.06; Published: 20I4.08.16

Abstract
We investigated the adipogenic activity of cultured human periosteal-derived cells and studied
perioxisome proliferator-activated receptor (PPAR) ligand-mediated differentiation of cultured
human periosteal-derived cells into osteoblasts. Periosteal-derived cells expressed adipogenic
markers, including CCAAT/enhancer binding protein $\alpha$ (C/EBP- $\alpha$ ), C/EBP-D, aP2, leptin, LPL, and
PPARY. Lipid vesicles were formed in the cytoplasm of periosteal-derived cells. Thus, perioste-
al-derived cells have potential adipogenic activity. The PPARa and PPARY agonists, WYI 4643 and
pioglitazone, respectively, did not modulate alkaline phosphatase (ALP) activity in perioste-
al-derived cells during induced osteoblastic differentiation, however, the PPARa and PPARY an-
tagonists, GW647I and T0070907, respectively, both decreased ALP activity in these cells.
WYI 4643 did not affect, whereas pioglitazone enhanced, alizarin red-positive mineralization and
calcium content in the periosteal-derived cells. GW647I and T0070907 both decreased miner-
alization and calcium content. By RT-PCR, pioglitazone significantly increased ALP expression in
periosteal-derived cells between culture day 3 and 2 weeks. Pioglitazone increased Runx2 ex-
pression after 3 days, which declined thereafter, but did not alter osteocalcin expression. Both of
GW647I and T0070907 decreased ALP mRNA expression. These results suggest that pioglita-
zone enhances osteoblastic differentiation of periosteal-derived cells by increasing Runx2 and ALP
mRNA expression, and increasing mineralization. GW647I and T0070907 inhibit osteoblastic
differentiation of the periosteal-derived cells by decreasing ALP expression and mineralization in
the periosteal-derived cells.
In conclusion, although further study will be needed to clarify the mechanisms of PPAR-regulated
osteogenesis, our results suggest that PPARy agonist stimulates osteoblastic differentiation of 
cultured human periosteal-derived cells and PPARa and PPARY antagonists inhibit osteoblastic differentiation in these cells.

Key words: Periosteal-derived cells; Adipogenic activity; Osteoblastic differentiation; PPAR ligands.

\section{Introduction}

Tissue engineering procedures for restoring bony defects offer significant advantages over autologous bone grafting, because bone grafting procedure could entail a complicated surgical procedure as well as potential morbidity at the donor site. Different cells have been used in tissue-engineered bone formation, including bone marrow-derived mesenchymal stem cells, periosteal-derived cells, and adipose-derived cells. Previously, we reported that the periosteal-derived cells differentiate into active osteoblastic cells that are involved in matrix mineralization [1-3]. Similar to bone marrow-derived mesenchymal stem cells, periosteal-derived cells contain multipotent cells with the potential to differentiate into osteoblasts and chondrocytes. The main advantage of using the periosteum for bone tissue engineering in a clinical setting is the relative ease of tissue harvesting through an intraoral procedure such as the surgical extraction of impacted third molar. Although several studies have reported osteogenic potential of periosteal-derived cells, adipogenic differentiation of cultured human periosteal-derived cells has not yet been fully investigated.

Osteoblasts, adipocytes, and various other mesenchymal lineage cells originate from multipotent mesenchymal stem cells, which display differentiation plasticity. Molecular regulators govern cell fate determination and switching, and in normal bone continuous osteoblastogenesis is maintained while adipogenesis appears to be suppressed. A precursor cell type differentiating along a specific cell lineage can be switched by genetic reprogramming into another cell type of a different lineage. Such fate decisions are regulated in part by transcription factors [4-7].

Peroxisome proliferator-activated receptors (PPARs) are ligand-activated transcription factors that belong to the superfamily of nuclear hormone receptors and play important roles in cellular differentiation, development, and metabolism. Three PPARs are currently known, PPARa, PPAR $\beta / \delta$, and PPAR $\gamma$. All PPARs share the same molecular mode of action by forming heterodimers with the nuclear retinoid $X$ receptor, followed by binding to peroxisome proliferator response elements on target genes. Expression of PPARa and PPAR $\beta / \delta$ is found ubiquitously, whereas PPARY is mainly expressed in adipose tissue, macrophages, and colon. PPARY is very specific to adipogenic differentiation and is induced before tran- scriptional activation of most adipocyte genes. PPARY is activated by natural ligands such as polyunsaturated fatty acids and prostaglandin metabolites, and by synthetic ligands such as the anti-diabetic thiazolidinedione group, whose members include rosiglitazone, pioglitazone, and troglitazone. Ectopic PPARY expression and activation induce adipocyte differentiation in many cell types that are not normally destined for this lineage [8-10]. Several studies have suggested possible adverse effects of PPARY on bone metabolism. Akune et al. [11] demonstrated that heterozygous PPAR $\gamma$-deficient (PPAR $\gamma+/-$ ) mice exhibit increased bone mass by stimulating osteoblastogenesis from bone marrow progenitors. Endogenous and synthetic PPARY agonists promote adipogenesis and inhibit osteoblastogenesis in primary bone marrow mesenchymal stem cell cultures. Treatment of mice with synthetic PPARY agonists decrease bone mineral density by suppressing the dominant osteoblastogenic transcriptional factors: Runx2, osterix, Dlx5, and a1(I)collagen [8,12-14]. However, the effects of PPAR ligands on cultured osteoprogenitor cells remain controversial $[9,15]$. This study examined the adipogenic activity of cultured human periosteal-derived cells. In addition, the effects of PPAR ligands on osteoblastic differentiation of cultured human periosteal-derived cells were also examined.

\section{Materials and Methods}

\section{Culture and Differentiation of Periosteal- Derived Cells}

Patients provided informed consent for collection of periosteal tissues, as required by the Ethics Committee of Gyeongsang National University Hospital. Periosteal explants $(5 \times 20 \mathrm{~mm})$ were harvested from mandibles during surgical extraction of impacted lower third molars. Periosteal pieces were cultured in $100 \mathrm{~mm}$ culture dishes in Dulbecco's Modified Eagle's Medium (DMEM) supplemented with $10 \%$ heat-inactivated fetal bovine serum (FBS), $100 \mathrm{IU} / \mathrm{mL}$ penicillin, and $100 \mu \mathrm{g} / \mathrm{mL}$ streptomycin, at $37^{\circ} \mathrm{C}$ in $95 \%$ humidified air and $5 \% \mathrm{CO}_{2}$. Upon reaching $90 \%$ confluence, adherent cells passaged by gentle trypsinization and reseeding in fresh medium.

Adipogenic differentiation was induced in confluent periosteal-derived cells by incubation in high-glucose DMEM containing L-glutamine, 10\% FBS, $1 \mathrm{IU} / \mathrm{mL}$ penicillin, $100 \mu \mathrm{g} / \mathrm{mL}$ streptomycin, 
$1 \mu \mathrm{M}$ dexamethasone, $100 \mu \mathrm{M}$ indomethacin, $500 \mu \mathrm{M}$ 3-isobutyl-1-methylxanthine, and $1 \mu \mathrm{g} / \mathrm{ml}$ insulin at a density of $3 \times 10^{5}$ cells/well in a six-well plate for 3 weeks. Media were changed every 3 days during adipogenic differentiation.

Osteoblastic differentiation was induced by culture of passage three periosteal cells in osteogenic induction medium composed of DMEM supplemented with $10 \%$ FBS, $50 \mu \mathrm{g} / \mathrm{ml}$ L-ascorbic acid 2-phosphate, $10 \mathrm{nM}$ dexamethasone, and $10 \mathrm{mM}$ $\beta$-glycerophosphate at a density of $3 \times 10^{4}$ cells/well in 24-well plates. Cells were differentiated for 21 days, with media changed every 3 days.

\section{Reverse Transcription-Polymerase Chain Reaction (RT-PCR) Analyses}

Total RNA was extracted from differentiating periosteal cells (cultured for various times in either adipogenic or osteoblastic induction media, as indicated) using Trizol ${ }^{\circledR}$ reagent (Invitrogen/Life Technologies Corp., CA, USA). Five $\mu$ g of total RNA was reverse transcribed by incubation with $5 \mathrm{pM}$ oligo(dT), $1 \mathrm{mM}$ of each dNTP, and $200 \mathrm{U}$ of Superscript $^{\mathrm{TM}}$ III reverse transcriptase (Invitrogen, CA, USA) in a total volume of $20 \mu \mathrm{l}$ at $50^{\circ} \mathrm{C}$ for $60 \mathrm{~min}$ followed by further incubated at $70^{\circ} \mathrm{C}$ for $15 \mathrm{~min}$ and rapid cooling on ice. Targeted genes were amplified by PCR with the primer sets listed in (Table 1), and products were electrophoresed on a $1.5 \%$ agarose gels containing ethidium bromide.

\section{Immunoblotting of aP2}

For detecting aP2 protein, periosteal cells that had been cultured in adipogenic media were lysed in NP-40 lysis buffer (20 mM Tris, pH 7.5, $140 \mathrm{mM} \mathrm{NaCl}$, $1 \mathrm{mM}$ EDTA, $1 \%$ (v/v) Nonidet P-40, $5 \mu \mathrm{M}$ AEBSF, 1.5 $\mathrm{nM}$ aprotinin, $10 \mathrm{nM} \mathrm{E-64,} \mathrm{and} 10 \mathrm{nM}$ leupeptin) for $30 \mathrm{~min}$, sonicated and centrifuged, and supernatants were treated in $20 \%$ trichloroacetic acid for $20 \mathrm{~min}$ at $4^{\circ} \mathrm{C}$, followed by centrifugation.at $31,000 \times \mathrm{g}$ for 20 min. Pellets were washed with $-20^{\circ} \mathrm{C}$ acetone, centrifuged at $31,000 \times \mathrm{g}$ for $30 \mathrm{~min}$, air dried, and resuspended in NP-40 lysis buffer. Proteins were resolved by SDS-PAGE and transferred to nitrocellulose membrane, which were probed with anti-aP2 antibody (Cat No.: sc-271529, Santa Cruz Biotechnology, CA, USA). Detection of aP2 protein expression was performed after 7,14 , and 21 days of culture in adipogenic induction medium.

\section{Cytoplasmic Lipid Vesicles in Periosteal-Derived Cells}

Oil Red O staining was used to identify cytoplasmic lipids in periosteal cells after 14 days of culture. Formaldehyde-fixed cells were stained for $1 \mathrm{~h}$ at room temperature with $0.3 \%$ Oil Red O (w/v) in $60 \%$ isopropanol, washed with distilled water, and visualized under light microscopy.

\section{Treatment of Periosteal-Derived Osteoblastic Cells with PPARa, PPARy Agonists and Antagonists}

Periosteal cells that had been cultured in osteogenic induction medium were treated with 0.1 to 25 $\mu \mathrm{M}$ PPARa agonist WY14643, 0.1 to $10 \mu \mathrm{M}$ PPARY agonist pioglitazone, 0.1 to $10 \mu \mathrm{M}$ PPARa antagonist GW6471, or 0.1 to $10 \mu \mathrm{M}$ PPAR $\gamma$ antagonist T0070907 (all from R\&D Systems, Minneapolis, USA). Media were changed every 3 days and the ligands were also added at each change of the medium.

\section{Histochemical Staining of Alkaline \\ Phosphatase (ALP), Alizarin Red S Staining and Calcium Quantification in Periosteal-Derived Osteoblasts}

ALP expression and mineralized nodule formation are the key factors to determine osteoblast differentiation. ALP and Runt-related transcription factor 2 (Runx2) are early markers for osteoblast differentiation, whereas, osteocalcin (OC) secretion and matrix mineralization are associated with the endpoint of full maturation of the osteoblast phenotype [1-3].

Table I. Primers for RT-PCR.

\begin{tabular}{|c|c|c|c|c|}
\hline Gene & Sequence $\left(5^{\prime} \rightarrow 3^{\prime}\right)$ & $\begin{array}{l}\text { Size } \\
\text { (bp) }\end{array}$ & Cycle & $\begin{array}{l}\text { Annealing } \\
\text { temp. }\end{array}$ \\
\hline \multirow[t]{2}{*}{ C/EBP-a } & (S) cggtggacaagaacagcaac & 365 & 30 & $58^{\circ} \mathrm{C}$ \\
\hline & (AS) cggaatctcctagtcctggc & & & \\
\hline \multirow[t]{2}{*}{$\mathrm{C} / \mathrm{EBP}-\beta$} & (S) cacagcgacgactgcaagatcc & 188 & 30 & $58^{\circ} \mathrm{C}$ \\
\hline & (AS) cttgaacaagttccgcagggtg & & & \\
\hline \multirow[t]{2}{*}{$\mathrm{C} / \mathrm{EBP}-\delta$} & (S) agcgcaacaacatcgccgtg & 267 & 30 & $58^{\circ} \mathrm{C}$ \\
\hline & (AS) gtcgggtctgaggtatgggtc & & & \\
\hline \multirow[t]{2}{*}{ PPAR- $\alpha$} & (S) ccagtatttaggacgctgtcc & 492 & 30 & $58^{\circ} \mathrm{C}$ \\
\hline & (AS) aagttcttcaagtaggccagc & & & \\
\hline \multirow[t]{2}{*}{ PPAR- $\beta / \delta$} & (S) aactgcagatgggctgtaac & 484 & 30 & $58^{\circ} \mathrm{C}$ \\
\hline & (AS) gtctcgatgtcgtggatcac & & & \\
\hline \multirow[t]{2}{*}{ PPARY } & (S) tgtctcataatgccatcaggtttg & 250 & 30 & $58^{\circ} \mathrm{C}$ \\
\hline & (AS) gataacgaatggtgatttgtctgtt & & & \\
\hline \multirow[t]{2}{*}{$\mathrm{aP2}$} & (S) accaggaaagtggctggcat. & 331 & 30 & $58^{\circ} \mathrm{C}$ \\
\hline & (AS) caggtcaacgtccettggct & & & \\
\hline \multirow[t]{2}{*}{ Leptin } & (S) tgccttccagaaacgtgatcc & 164 & 35 & $58^{\circ} \mathrm{C}$ \\
\hline & (AS) ctctgtggagtagcctgaagc & & & \\
\hline \multirow[t]{2}{*}{ LPL } & (S) gagatttctctgtatggcacc & 276 & 30 & $58^{\circ} \mathrm{C}$ \\
\hline & (AS) ctgcaaatgagacactttctc & & & \\
\hline \multirow[t]{2}{*}{ GAPDH } & (S) aatgcatcctgcaccaccaa & 515 & 30 & $58^{\circ} \mathrm{C}$ \\
\hline & (AS) gtagccatattcattgtcat & & & \\
\hline
\end{tabular}

For ALP histochemical staining, formaldehyde/ethanol-fixed periosteal-derived osteoblastic cells were stained with fast 5-bromo-4-chloro-3indolyl phosphate and nitroblue tetrazolium (BCIP/NBT) ALP substrate (Amresco LLC, OH, USA), and viewed by light microscopy. Staining for 
ALP was performed after 3,7 , and 14 days of culture in osteoblast induction medium.

The alizarin red $S$ technique was used to assess mineralized nodule formation and quantify calcium contents of deposits. Formaldehyde-fixed cells were treated with a $2 \%$ alizarin red $S$ solution for 5 minutes and washed with distilled water to remove residual stain. Alizarin red S-stained cultures were incubated with $100 \mathrm{mM}$ cetylpyridinium chloride (Sigma-Aldrich, MO, USA) for 2 hours to release calcium-bound alizarin, which was measured at $570 \mathrm{~nm}$ with a microplate reader. Alizarin red S staining was evaluated at day 21 of culture.

Periosteal-derived osteoblastic cells were decalcified with $0.6 \mathrm{~N} \mathrm{HCl}$ for $24 \mathrm{~h}$, and the calcium content of supernatants was determined by spectrophotometry using the o-cresolphthalein method (Calcium C-test Wako, Wako Pure Chemical Industries, Osaka, Japan). After decalcification, the total protein content in the supernatants was measured using a BCA protein assay kit (Pierce Chemical Co, IL, USA). Cellular calcium content was normalized to total protein content. Calcium content was examined at day 21 of culture.

\section{Quantitative RT-PCR Analysis}

We performed quantitative RT-PCR for ALP, OC, and Runx2 with total RNA extracted from differentiating periosteal-derived osteoblastic cells at indicated times. First-strand cDNA was generated using random hexamer primers provided in the first-strand cDNA synthesis kit (Applied Biosystems Inc., MA, USA). All primers and probes (GAPDH Cat \# Hs02758991-g1; OC Cat \# Hs00609452-g1; Runx2 Cat \# Hs00231692-m1; ALP \#Hs01029144-m1) were obtained commercially (TaqMan ${ }^{\circledR}$ Gene Expression Assay, Applied Biosystems Inc.) and amplified using a kit and following manufacturer instructions (TaqMan ${ }^{\circledR}$ Gene Expression Master Mix, Applied Biosytems). Amplification conditions were: $50^{\circ} \mathrm{C}, 2 \mathrm{~min}$; $95^{\circ} \mathrm{C}, 10 \mathrm{~min}$; followed by 40 cycles of $94^{\circ} \mathrm{C}, 15 \mathrm{~s}$ and $60^{\circ} \mathrm{C}, 1$ min in 96-well plates using the ViiA ${ }^{\mathrm{TM}} 7 \mathrm{Re}-$ al-Time PCR System (Applied Biosystems Inc.). GAPDH was used as an internal control. All experiments were performed in triplicate.

Periosteal-derived osteoblastic cells were treated with 5 and $25 \mu \mathrm{M}$ PPARa agonists, 5 and $10 \mu \mathrm{M}$ PPAR $\gamma$ agonists, 5 and $10 \mu \mathrm{M}$ PPARa antagonists, and
5 and $10 \mu \mathrm{M}$ PPAR $\gamma$ antagonists, respectively.

\section{Statistical Analysis}

All experiments were performed using triplicate cultures, with the results expressed in each experiment as the mean \pm standard deviation (SD). Statistical analyses were conducted using the GraphPad Prism software (GraphPad Software, CA, USA). Data were evaluated by one-way ANOVA with Tukey's multiple comparison tests. Differences with a p-value $<0.05$ were considered statistically significant.

\section{Results}

\section{Adipogenic Differentiation of Cultured Human Periosteal-derived Cells}

Periosteal-derived cells showed a fibroblastic morphology in the primary cell cultures. Culture in adipogenic differentiation media converted cells to a spherical morphology with accumulated lipid droplets. These periosteal-derived cells were positive for several adipogenic marker genes. By western blotting, aP2 protein expression was induced in a time dependent fashion between weeks 1 and 3. By RT-PCR, gene expression of CCAAT/enhancer binding protein a (C/EBP-a), C/EBP- $\delta$, aP2, leptin, LPL, and PPAR $\gamma$ were increased in these cells (Fig. 1). These results suggest that cultured human periosteal-derived cells differentiated into active adipogenic cells that synthesize cytoplasmic lipid vesicles.

\section{Expression of PPAR Subtypes during Osteoblastic Differentiation of Cultured Human Periosteal-derived Cells}

PPAR $\alpha$ and PPAR $\gamma$ mRNAs were more highly expressed in osteogenic induction DMEM than in control DMEM at day 3. PPAR $\alpha$ expression in the periosteal-derived osteoblastic cells first appeared at day 3, and decreased during the remaining culture period. PPAR $\gamma$ mRNA was clearly upregulated after 7 days culture in osteogenic induction media, after which its expression decreased in periosteal-derived osteoblastic cells. However, PPAR $\beta / \delta$ expression was constant in the periosteal-derived osteoblastic cells throughout the 17 day observation period, in both control DMEM and osteogenic DMEM cultures (Fig. 2). 
A

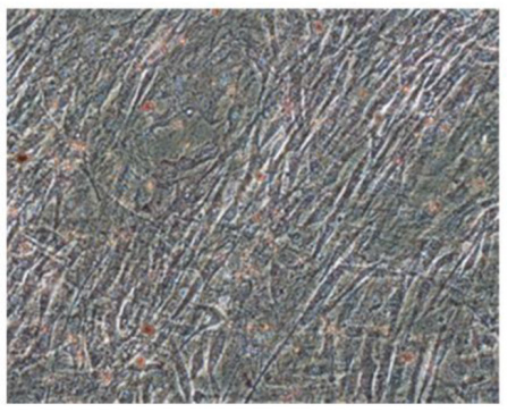

AM

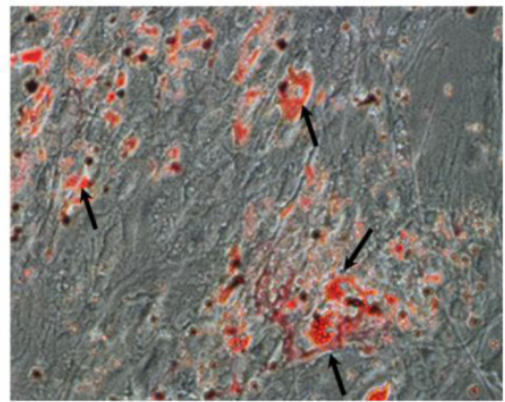

B

$$
\text { 1W } 2 W \quad 3 W
$$
AM

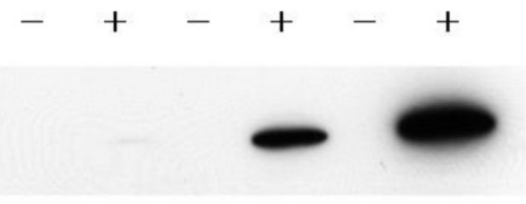
aP2

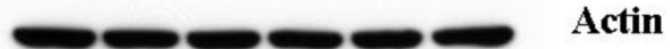

$\mathrm{C} \quad \frac{1 \mathrm{~W}}{-+} \frac{2 \mathrm{~W}}{-+} \frac{3 \mathrm{~W}}{-+} \frac{1 \mathrm{~W}}{-+} \frac{2 \mathrm{~W}}{-+} \frac{3 \mathrm{~W}}{-+}$

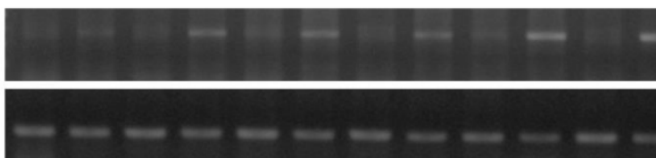

C/EBP- $\alpha$

C/EBP- $\beta$

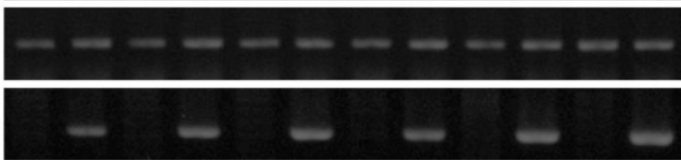

C/EBP- $\delta$

aP2

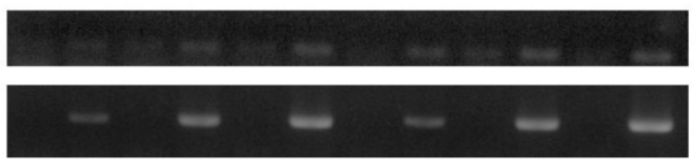

leptin

LPL

D $\quad \frac{1 \mathrm{~W}}{-+} \frac{2 \mathrm{~W}}{-++} \frac{3 \mathrm{~W}}{-++} \frac{1 \mathrm{~W}}{-++} \frac{2 \mathrm{~W}}{-+} \frac{3 \mathrm{~W}}{-+}$
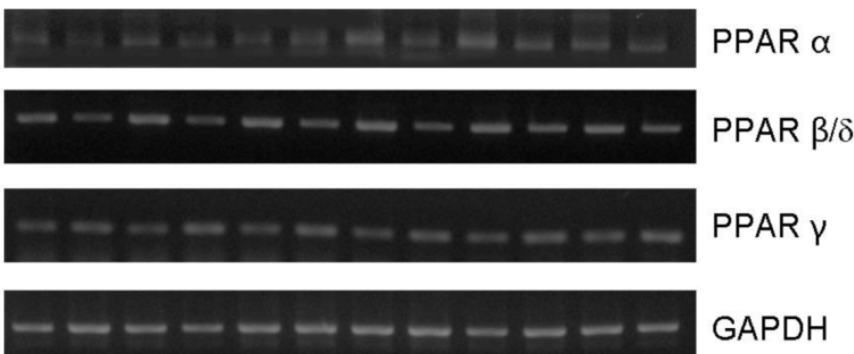

GAPDH

Figure I. Adipogenic differentiation of cultured human periosteal-derived cells. A: Oil Red O staining of periosteal-derived cells showed accumulation of lipids in cytoplasmic vesicles (arrows) after 2 weeks ( $2 \mathrm{~W}$ ) of culture in adipogenic differentiation medium. B: In immunoblotting analysis, aP2 expression first appeared at I week (IW) followed by increased expression during the subsequent 2 week culture period. C\&D: By RT-PCR, gene expression of CCAAT/enhancer binding protein- $\alpha$ (C/EBP- $\alpha$ ), C/EBP- $\delta$, aP2, leptin, LPL, and PPARY were clearly increased in these periosteal-derived cells. AM; adipogenic differentiation medium. 


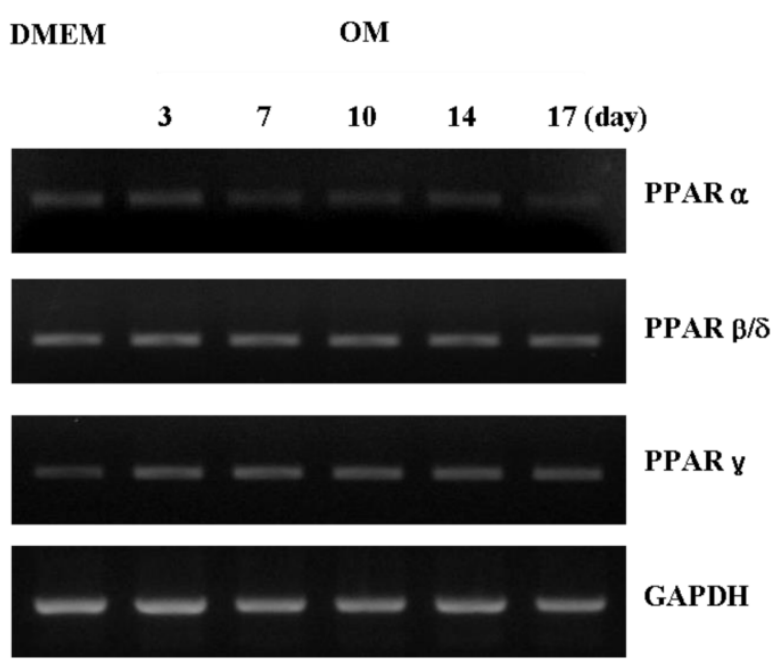

Figure 2 Expression of PPAR subtypes during osteoblastic differentiation of cultured human periosteal-derived cells. Expression of PPARa and PPARy in periosteal-derived cells differed between culture in osteogenic induction DMEM (OM) versus control DMEM, whereas expression of PPAR $/ \delta$ was constant. OM; osteogenic induction DMEM medium.

\section{ALP Activity in the Periosteal-derived Osteoblastic Cells treated with PPARa or PPARY Ligands}

Treatment with either the PPAR $\alpha$ agonist (WY14643) or the PPAR $\gamma$ agonist (pioglitazone) did not affect ALP histochemical activity in the periosteal-derived osteoblastic cells. However, both PPAR $\alpha$ antagonists (GW6471) and PPAR $\gamma$ antagonist (T0070907) clearly decreased ALP activity in a concentration-dependent manner during 14 days in culture. PPAR $\gamma$ antagonist with T0070907 reduced ALP activity to a greater extent that did PPAR $\alpha$ antagonist with GW6471 in periosteal-derived cells that were cultured in osteoblastic differentiation medium (Fig. $3)$.

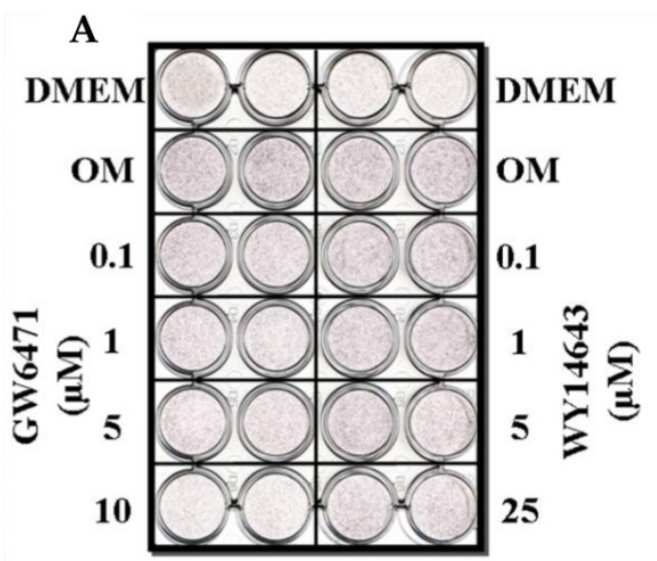

3 days

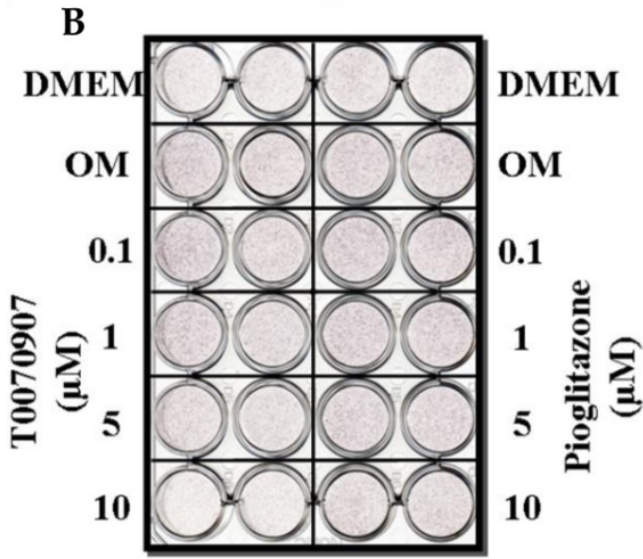

3 days

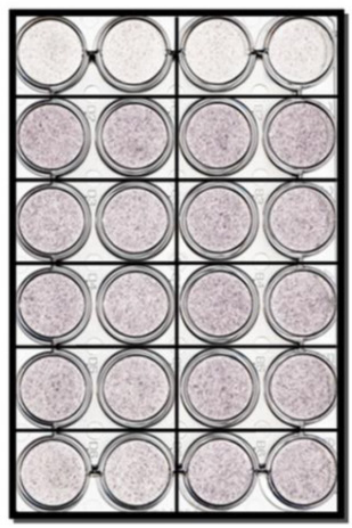

7 days

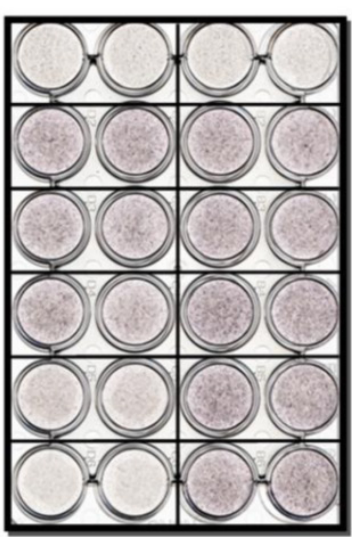

7 days

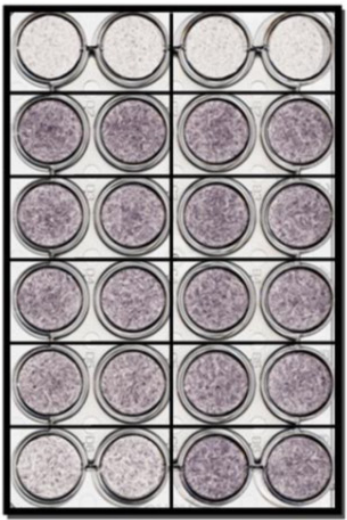

14 days

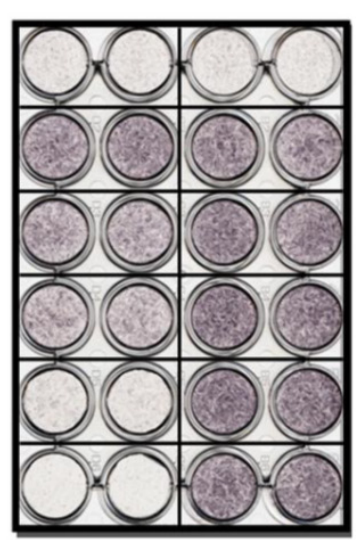

14 days

Figure 3 Histochemical staining of ALP activity in periosteal-derived cells differentiated in osteoblastic induction media and treated with PPAR $\alpha$ or PPARY ligands. A: The PPAR agonist WY 14643 did not affect ALP activity; however, the PPARa antagonist GW647I decreased ALP activity in a concentration- and time-dependent manner during the 2 week culture period. B: Similar to the effects of PPARa ligands, treatment with the PPARY agonist pioglitazone did not affect ALP activity in the periosteal-derived cells during osteoblastic differentiation, while, PPARY antagonist with T0070907 definitely decreased ALP activity in a concentration-dependent manner. OM; osteogenic induction DMEM medium. 


\section{Effects of PPARa or PPARY Ligands on Mineralization}

Although $5 \mu \mathrm{M}$ WY14643 significantly increased calcium contents in periosteal-derived osteoblastic cells, the PPAR $\alpha$ agonist WY14643 did not alter alizarin red-positive mineralization and calcium content in the periosteal-derived cells. Conversely, however, the PPAR a antagonist GW6471 decreased both alizarin red-positive mineralization and calcium content in periosteal-derived osteoblastic cells. The PPAR $\gamma$ agonist pioglitazone clearly enhanced both mineralization and calcium content in a concentration-dependent manner in osteoblast-differentiating periosteal-derived cells, whereas the PPAR $\gamma$ antagonist T0070907 concentration-dependently decreased mineralization and calcium content in these cells (Fig. $4)$.

\section{Quantitative RT-PCR Analysis}

Baseline ALP mRNA expression was time-dependently increased (through 3 weeks) by culture in osteogenic-induction medium. Treatment with the PPAR $\alpha$ agonist WY14643 significantly increased ALP expression above these control levels at 1 and 2 weeks of culture, but had no effect beyond osteogenic medium-induced ALP mRNA at 3 weeks. Treatment of these cells with the PPAR $\alpha$ antagonist GW6471 caused a concentration- and time-dependent inhibition of ALP mRNA expression in these cells. Pioglitazone, the PPAR $\gamma$-agonistic ligand, significantly increased osteogenic induction medium-induced ALP mRNA expression through 2 weeks of exposure, but had this effect disappeared at 3 weeks. Conversely, the PPAR $\gamma$-antagonistic ligand T0070507 decreased osteogenic differentiation medium-induced ALP upregulation throughout the 3 week experimental course.
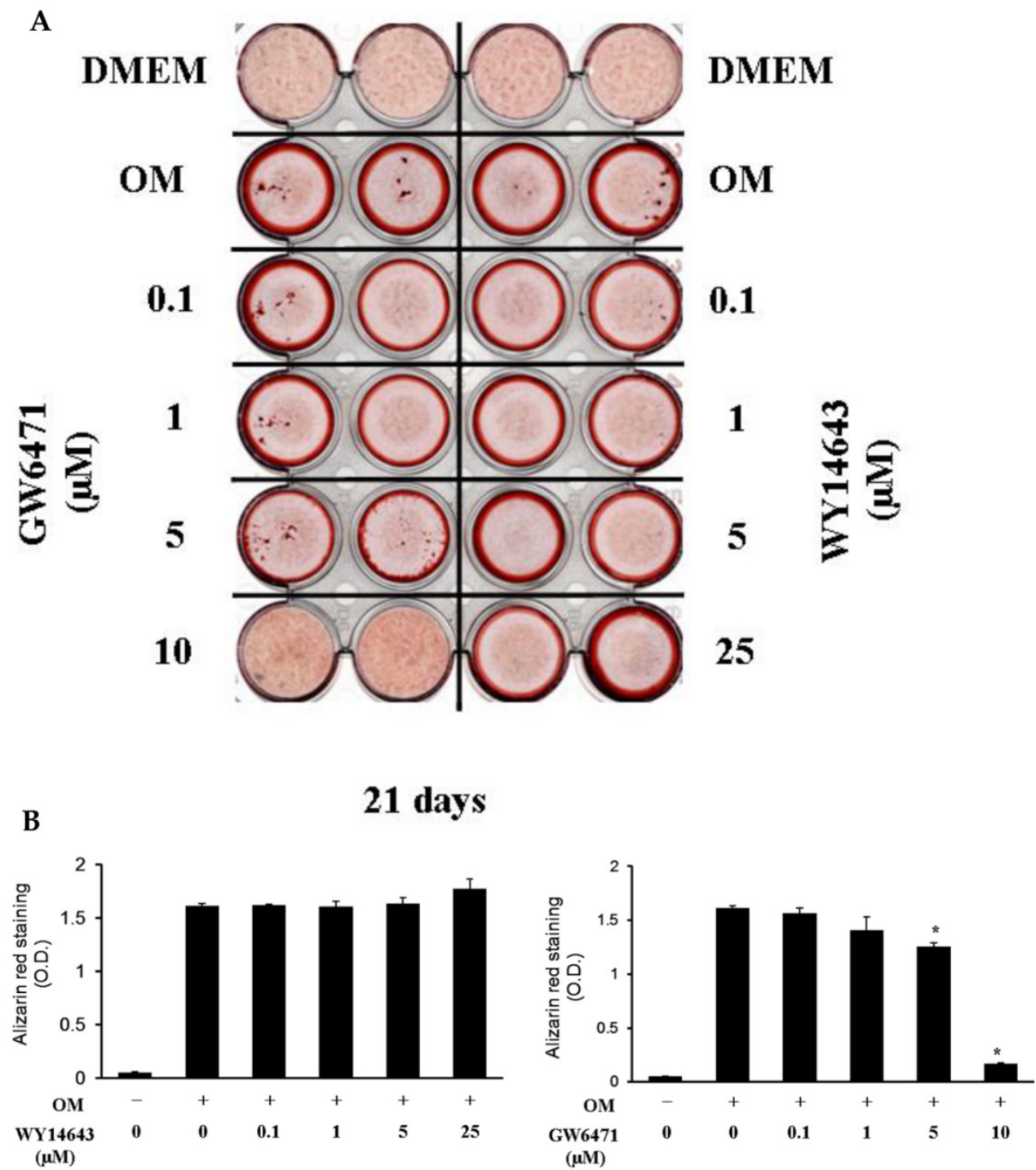
C
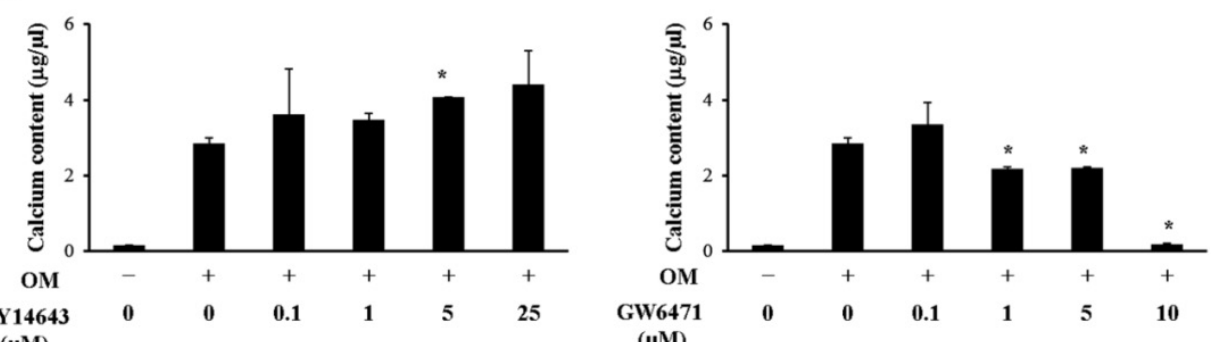

$(\mu \mathrm{M})$

D

\section{DMEM}

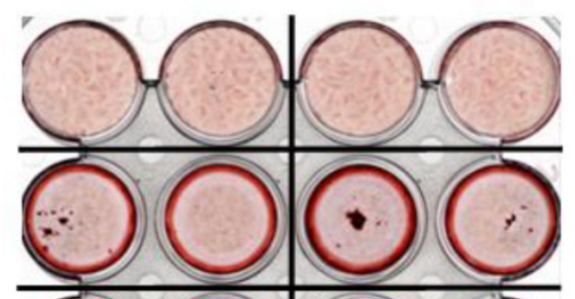

DMEM

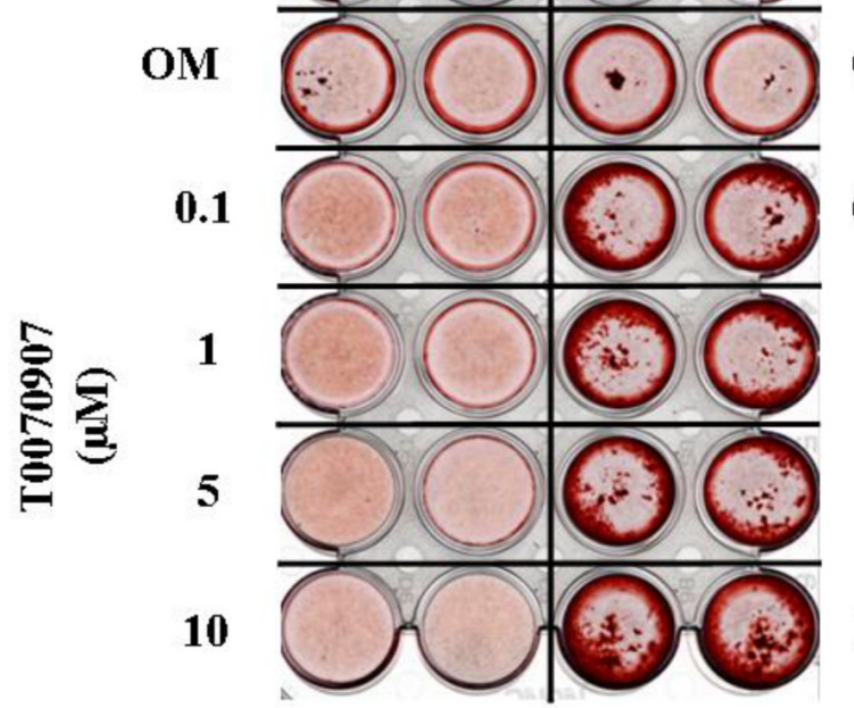

OM

\section{1}

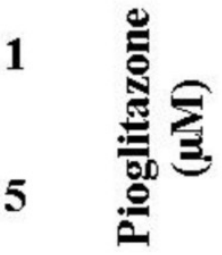

E

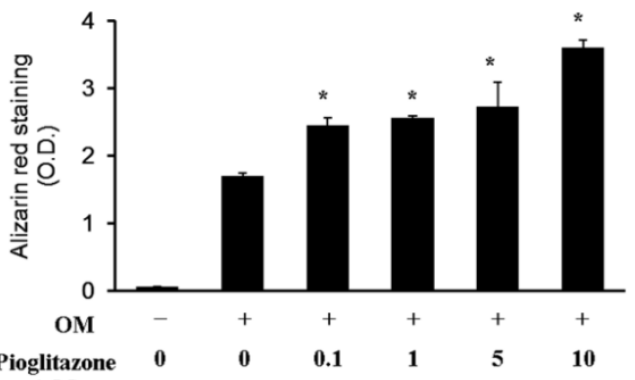

$(\mu \mathrm{M})$

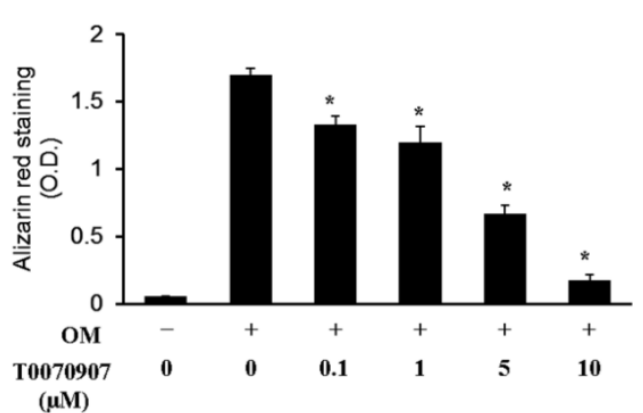

F
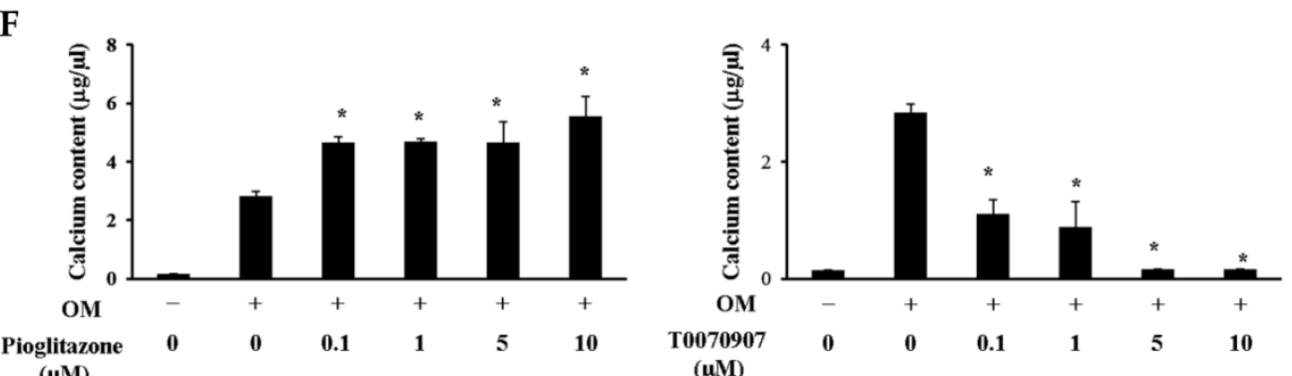

Figure 4 Effects of PPAR $\alpha$ or PPARy ligands on mineralization and calcium content of periosteal-derived osteoblastic cells. A, B\&C: Mineralization of periosteal-derived osteoblastic cells was unaffected by PPAR $\alpha$ agonist WYI4643 treatment after 21 days of treatment. However, WYI4643 tended to modestly increase calcium content, which reached statistical significance at $5 \mu \mathrm{M}$ WY I4643. The PPAR $\alpha$ antagonist GW647I, however, significantly decreased alizarin red-positive mineralization and calcium content in periosteal-derived osteoblastic cells, particularly at high concentrations (i.e., $>5 \mu$ M for mineralization and $>1 \mu M$ for calcium content). D, E\&F: The PPAR $\gamma$ agonist pioglitazone clearly enhanced mineralization and calcium content in periosteal-derived osteoblastic cells. The PPAR $\gamma$ antagonist T0070907 decreased mineralization and calcium content in periosteal-derived cells cultured in osteogenic-differentiation medium, in a concentration dependent fashion. $*$ p $<0.05$ versus values observed in cells cultured in osteogenic induction DMEM media (OM+) without PPAR ligand treatment. 
Baseline OC expression in cultured periosteal-derived osteoblastic cells increased modestly between through 3 weeks in culture. After 1 week in osteogenic differentiation medium, the PPARa agonist WY14643 significantly but transiently increased OC expression, with levels declining to or below control levels at weeks 2 and then increasing again above control levels at week 3. The PPARa antagonist GW6471 decreased OC mRNA levels at 1 and 2 weeks in culture, but OC mRNA levels returned to control levels after 3 weeks of stimulation. Pioglitazone, the PPARY agonist, significantly increased OC expression in these cells after 3 weeks in culture, whereas the PPARY antagonist T0070507 decreased OC mRNA expression relative to osteogenic induction media-only controls, beginning at 2 weeks of stimulation.
The PPARa agonist WY14643 transiently increased Runx 2 mRNA expression at 1 week of culture, with mRNA levels no different from controls thereafter. The PPARa antagonist GW6471 caused a modest decrease in Runx2 mRNA expression after 1-2 weeks of stimulation, which was not apparent at 3 weeks. The PPAR $\gamma$-agonistic ligand pioglitazone significantly increased Runx2 mRNA expression in osteoblast-induced periosteal-derived cells after 3 days in culture. However, pioglitazone markedly decreased Runx2 expression in these cells thereafter through at least 3 weeks of culture. The PPARY antagonist T0070907 decreased Runx2 mRNA expression in these periosteal-derived osteoblastic cells, beginning at 1 week of treatment and persisting for at least 3 weeks (Fig. 5).

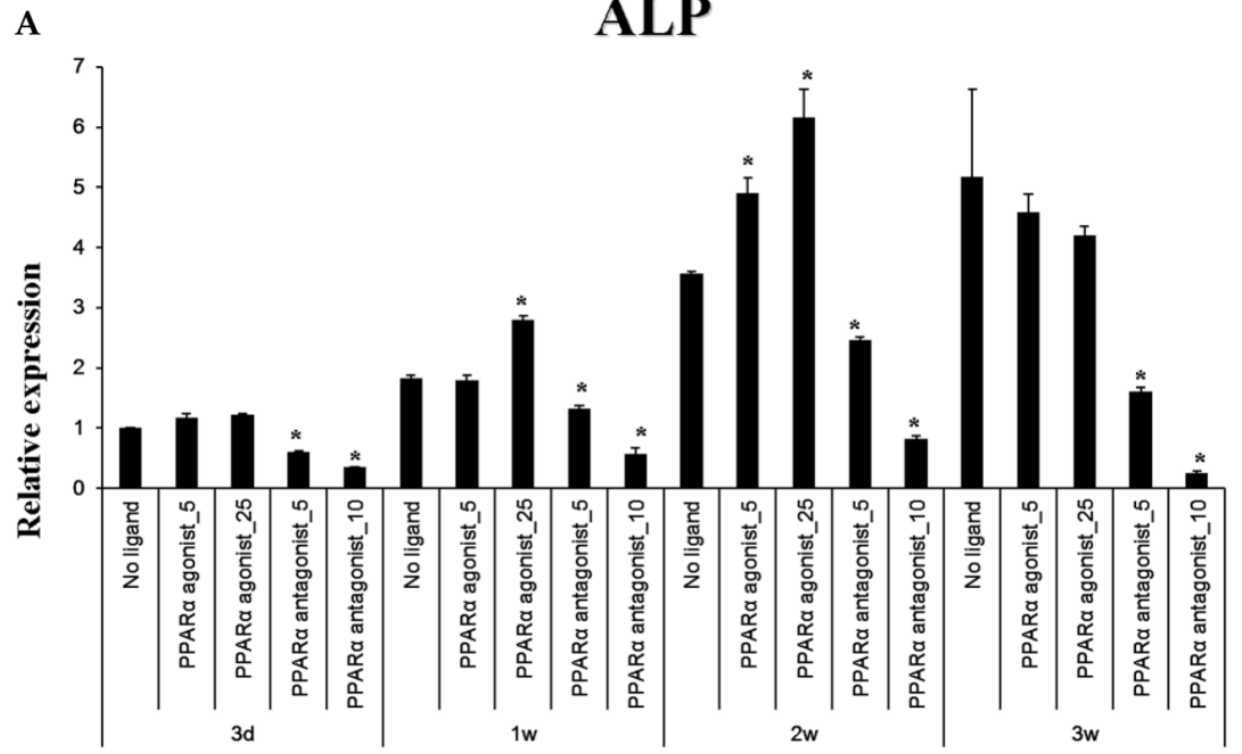

A

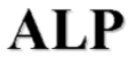

B

ALP

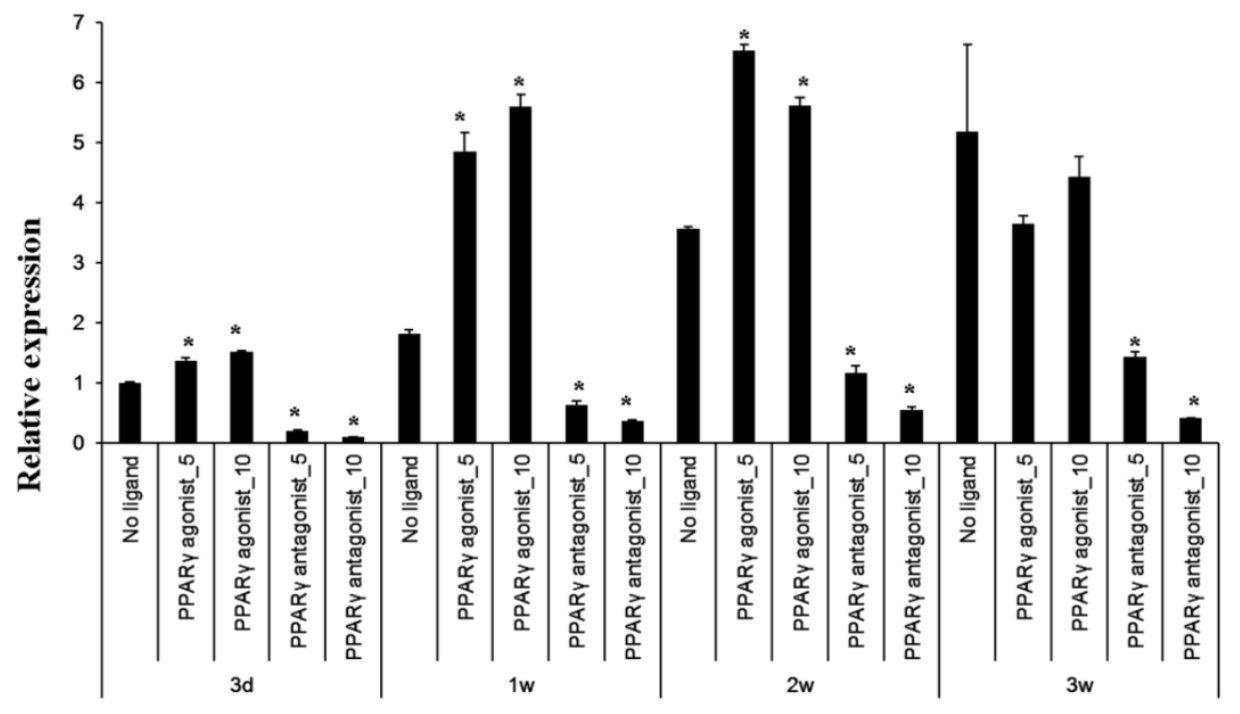



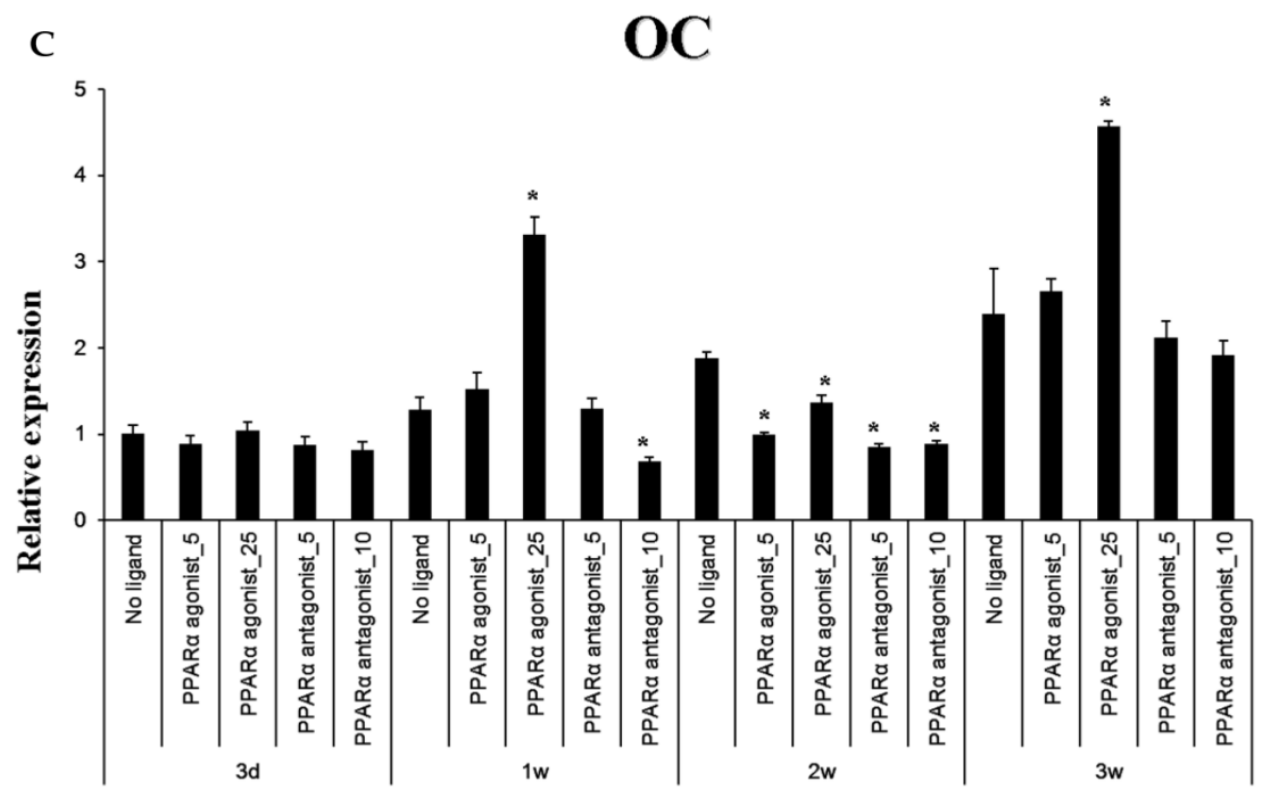

D

OC

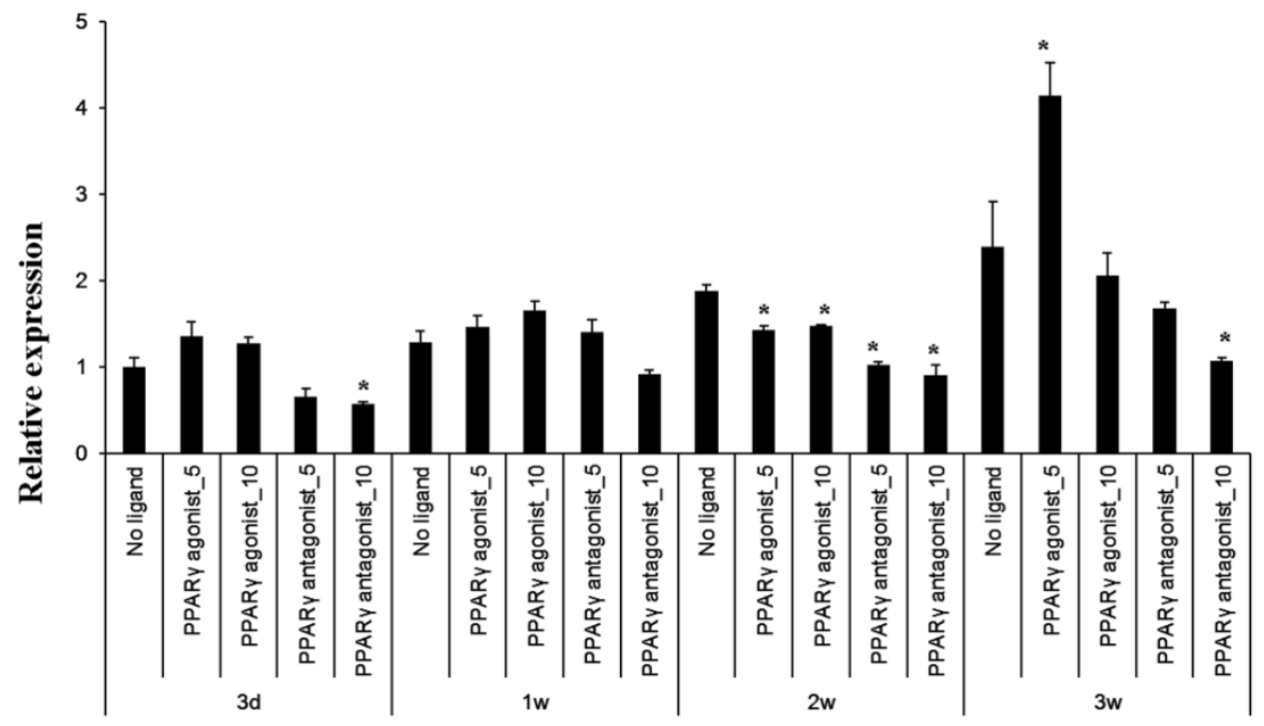




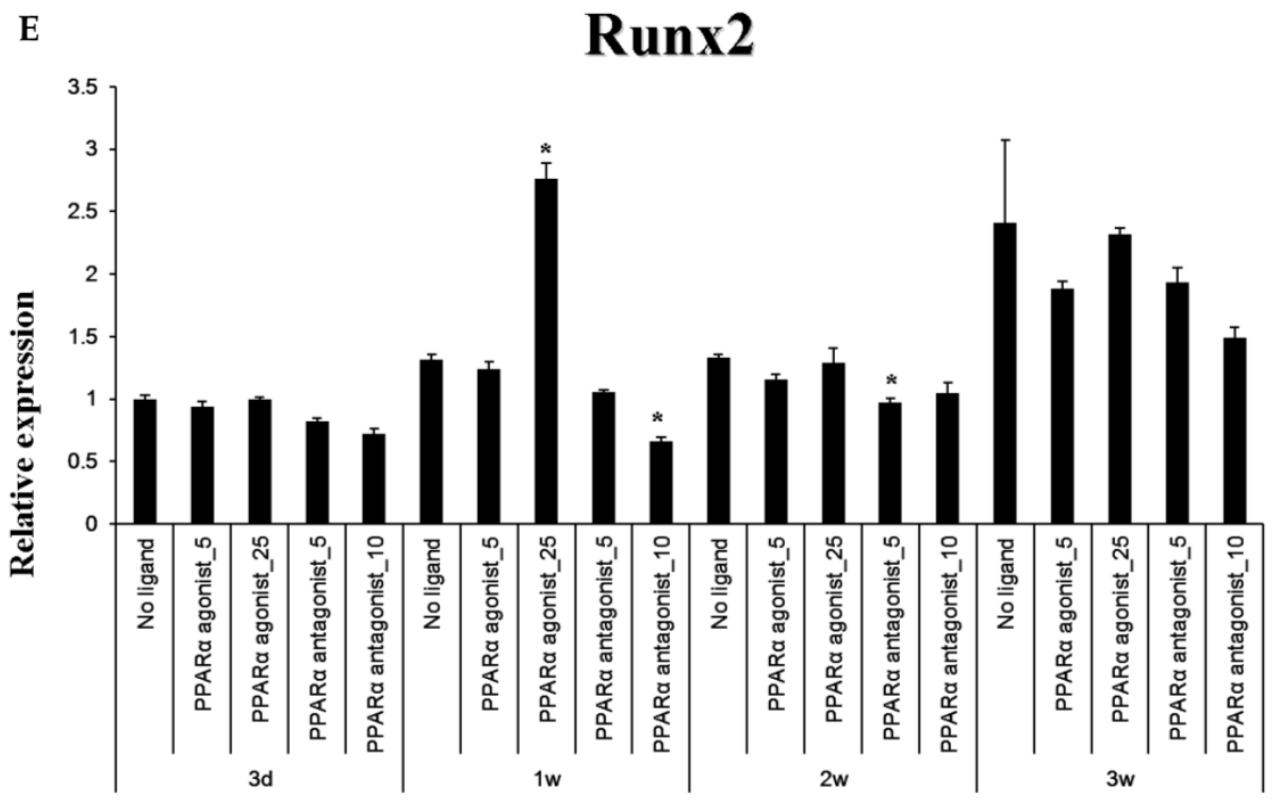

F

Runx2

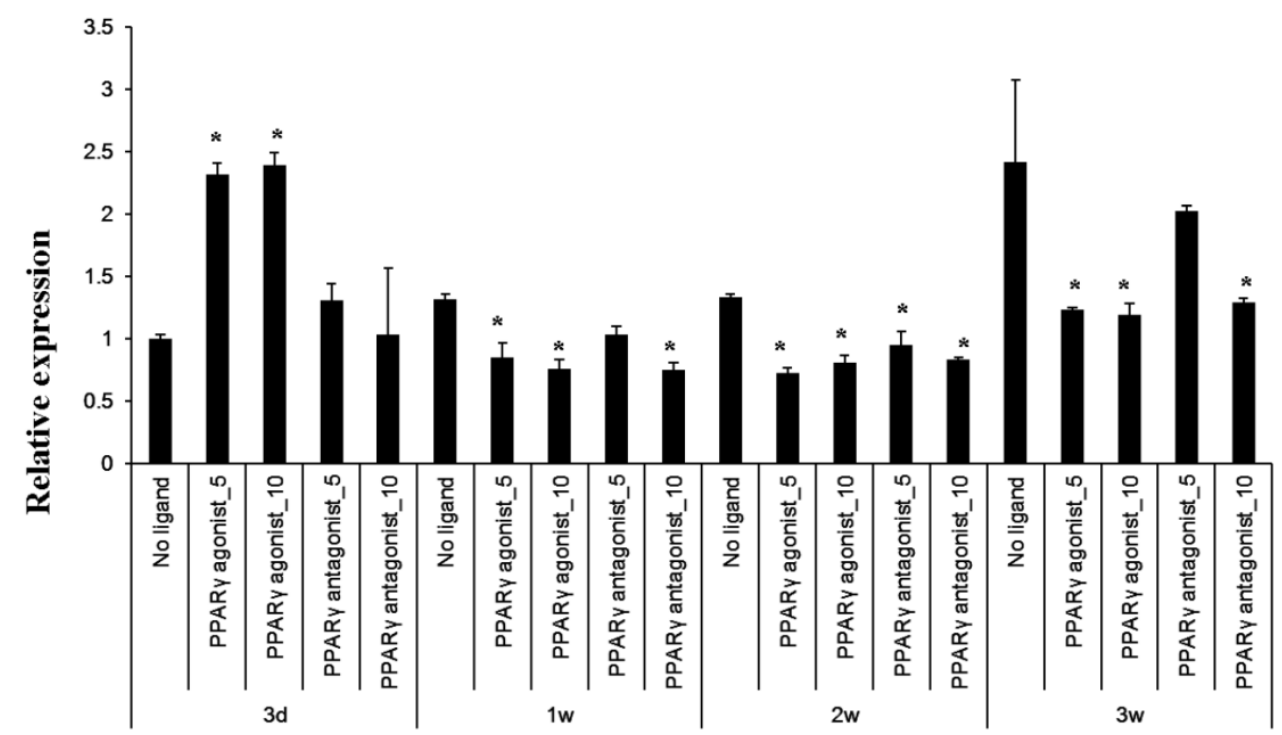

Figure 5 Quantitative RT-PCR analysis. A\&B: ALP mRNA expression in the periosteal-derived osteoblastic cells treated with PPAR $\alpha$ or PPAR $\gamma$ ligands. C\&D: OC mRNA expression in the periosteal-derived osteoblastic cells treated with PPAR $\alpha$ or PPAR $\gamma$ ligands. E\&F: Runx2 mRNA expression in the periosteal-derived osteoblastic cells treated with PPAR $\alpha$ or PPAR $\gamma$ ligands. PPAR $\alpha$ agonist_5; $5 \mu$ M PPAR $\alpha$ agonist, PPAR $\alpha$ agonist_25; $25 \mu$ M PPAR $\alpha$ agonist, PPAR $\alpha$ antagonist_5; $5 \mu M$ PPAR $\alpha$ antagonist, PPAR $\alpha$ antagonist_10; $10 \mu$ MPPAR $\alpha$ antagonist, PPAR $\gamma$ agonist_5; $5 \mu$ MPPAR $\gamma$ agonist, PPAR $\gamma$ agonist_10; $10 \mu$ M PPAR $\gamma$ agonist, PPAR $\gamma$ antagonist_5; $5 \mu$ M PPAR $\gamma$ antagonist, PPAR $\gamma$ antagonist_10; $10 \mu \mathrm{M}$ PPAR $\gamma$ antagonist.

\section{Discussion}

Osteoblasts and adipocytes and other mesenchymal lineage cells originate from multipotent mesenchymal progenitor cells. Cultured human periosteal-derived cells can be differentiated into adipogenic lineage cells. In the present study, we examined the adipogenic differentiation of cultured human periosteal-derived cells. Adipocyte differentiation is characterized by the expression of particular genes that determine the specific adipocyte phenotype. Two transcriptional factors, C/EBP-a and PPARY have been shown to transactivate adipocyte-specific genes that are involved in the growth arrest required for adipocyte differentiation. In addition, C/EBP- $\beta$, C/EBP- $\delta$, aP2, leptin, and LPL are well-known adipogenic markers. During the terminal phase of differentiation, adipocytes in culture markedly increase de novo lipogenesis and cytoplasmic lipid vesicle formation is a late marker of adipogenesis $[5,16]$. In the present study, human periosteal-derived cells that were cultured in adipogenic induction medium became positive for these adipogenic markers and accumulated cytoplasmic lipid droplets. These results suggest that the cultured human periosteal-derived cells have good adipogenic activity and are a good 
candidate application requiring tissue-engineered fat. Mesenchymal stem cells are a multipotent cell type that can give rise not only to osteoblasts, but also to a range of other cell types including adipocytes, chondrocytes, and myoblasts. The differentiation fate of mesenchymal stem cells is determined in large measure by a complex interplay of extracellular signaling molecules such as growth factors, hormones, and nutrients that affect the expression and activation of lineage-specific transcription factors. The key transcription factors Runx2 and PPARY act as molecular switches to direct differentiation of precursor cells into osteoblasts or adipocytes, respectively. Recent studies have shown that PPARY activity directly inhibits osteogenesis by diverting mesenchymal stem cells from the osteogenic phenotype to the adipogenic lineage. This shift in mesenchymal stem cell differentiation to favor the adipocyte lineage over the osteoblast lineage directly contributes to imbalances in bone formation and resorption, and ultimately leads to bone loss $[8,10,17,18]$.

In this study, we have examined the effects of PPARa and PPARY ligands on in vitro osteoblastic differentiation of cultured human periosteal-derived cells. The expression of PPAR $\beta / \delta$ was constant in the periosteal-derived cells cultured with or without osteogenic induction medium, so we did not examine effects of PPAR $\beta / \delta$ ligands on osteoblastic differentiation of these cells.

Expression of the PPARa is highest in tissues with active fatty acid catabolism, including liver, heart, small and large intestine, and skeletal muscle. The role of PPARa in these tissues is to regulate fatty acid catabolism. Although the role of PPARa ligands in bone metabolism remains poorly elucidated, several studies demonstrated that PPARa agonists suppress osteoclast differentiation by inhibiting nuclear factor kappa B (NF- $\kappa$ B) signaling [19-21]. In a study examining the effects of PPARa and PPARY agonists on bone in intact female rats, Syversen et al [22] demonstrated that PPARa agonist caused significantly increased femoral bone mineral density and lower medullary volume. Stunes et al [23] also examined the positive effect of PPARa agonists on bone in a study using ovariectomized rats. Takano et al [10] suggested that that PPARa agonist, but not PPARY agonist, upregulates the dominant osteoblastogenic transcriptional factors, Runx2, osteocalcin, and collagen type-I induced by bone morphogenic protein- 4 in the mouse myoblastic cell line C2C12.

PPARY is well established as a prime regulator that stimulates adipogenesis in multipotent mesenchymal stem cells. Treatment of primary bone marrow mesenchymal stem cells and mesenchymal stem cell lines with PPARY agonists promotes adipogene- sis. In relation to bone homeostasis, many studies reported that PPARY agonist inhibits osteoblastogenesis in animals and humans. Natural and synthetic PPARy agonists inhibit osteoblastogenesis in murine marrow-derived UAMS-33 cells. PPARy haplo-insufficient mice showed increased trabecular bone volume associated with a loss of adipose tissue volume [8,14,24-27]. In human, administration of PPAR agonist results in progressive bone loss and diminished levels of circulating bone formation markers in older women. Additionally, PPARY agonist increases the rate of fracture in diabetic human subjects [28-30]. Therefore, PPAR $\gamma$ could serve as a useful target for drugs intended to enhance bone mass. However, the effects of PPAR ligands on the differentiation of cultured osteoprecursor cells are still controversial. Jackson et al [8] reported that PPARa and PPARY activators induce the osteoblastic maturation of MC3T3-E1 mouse osteoprecursor cells. However, they observed that reduced ALP activity and calcium content occurred at higher PPARY activator concentrations. In human bone marrow-derived mesenchymal stem cells, Yu et al [15] reported that PPARY inhibitors reduced the extent of adipogenesis, but did not significantly affect osteogenesis. They observed that PPARY inhibition did not significantly influence expression of the major osteogenic transcription factor Runx2.

In the present study, treatment with the PPARa agonist WY14643 largely did not affect the histochemical activity of ALP, mineralization, and calcium content in the periosteal-derived cells that were cultured in osteogenic induction medium. Although PPARY agonist pioglitazone treatment did not stimulate the ALP activity in these cells, pioglitazone significantly increased Runx2 mRNA expression at day 3 , and ALP mRNA expression at day 3 and 1 and 2 weeks of culture. Conversely, pioglitazone significantly decrease Runx2 mRNA expression in periosteal-derived osteoblastic cells between weeks 1 and 3. In addition, pioglitazone clearly enhanced mineralization and calcium content in the periosteal-derived osteoblastic cells. Especially, pioglitazone at the highest concentration $(\geq 10 \mu \mathrm{M})$ employed in this study appreciably enhanced alizarin red-positive mineralization of periosteal-derived osteoblastic cells. Considering that ALP and Runx2 are early markers of osteoblast differentiation, whereas osteocalcin secretion and matrix mineralization are associated with the late phase of osteoblast differentiation, our results suggest that pioglitazone enhances osteoblastic differentiation of the cultured human periosteal-derived cells by increasing Runx 2 and ALP expression at earlier times and increasing mineralization at later time points. 
The PPARa antagonist GW6471 and the PPARY antagonist T0070907 decreased the histochemical detection of ALP activity and ALP mRNA expression in the periosteal-derived osteoblastic cells. GW6471 and T0070907 tended to decrease alizarin red-positive mineralization and calcium content of periosteal-derived osteoblastic cells in a dose-dependent manner during the culture period. These PPAR antagonists also decreased OC expression in the periosteal-derived cells at 2 weeks of culture. These results suggest that both of GW6471 and T0070907 inhibit osteoblastic differentiation of the periosteal-derived cells by decreasing ALP activity and mineralization of the periosteal-derived cells.

To our knowledge, evidence regarding the effects of PPAR ligands on cultured human periosteal-derived cells has been limited. The primary findings of this study are that PPARY agonist stimulates osteoblastic differentiation of cultured human periosteal-derived cells and PPARa and PPARY antagonists inhibit osteoblastic differentiation in these cells. Further study is needed to clarify the mechanisms of PPAR-regulated osteogenesis.

\section{Acknowledgements}

This research was supported by Basic Science Research Program through the National Research Foundation of Korea (NRF) funded by the Ministry of Education, Science and Technology (2012R1A1A2038795). This study was also supported by a grant of the Korean Health Technology R\&D Project, Ministry of Health \& Welfare, Republic of Korea (HI13C1596).

\section{Competing Interests}

The authors have declared that no competing interest exists.

\section{References}

1. Park BW, Hah YS, Kim DR, Kim JR, Byun JH. Osteogenic phenotypes and mineralization of cultured human periosteal-derived cells. Arch Oral Biol. 2007;52(10):983-989.

2. Park BW, Hah YS, Kim DR, Kim JR, Byun JH. Vascular endothelial growth factor expression in cultured periosteal-derived cells. Oral Surg Oral Med Oral Pathol Oral Radio Endod. 2008;105(5):554-560.

3. Ryu YM, Hah YS, Park BW, Kim DR, Roh GS, Kim JR, Kim UK, Rho GJ, Maeng $\mathrm{GH}$, Byun JH. Osteognic differentiation of human periosteal-derived cells in a three-dimensional collagen scaffold. Mol Biol Rep. 2011;38(5):2887-2894.

4. Beresford JN, Bennett JH, Devlin C, Owen MEC. Evidence for an inverse relationship between the differentiation of adipocytic and osteogenic cells in rat marrow stromal cell cultures. J Cell Sci. 1992;102(2):341-351.

5. Schilling T, Nöth U, Klein-Hitpass L, Jakob F, Schütze N. Plasticity in adipogenesis and osteogenesis of human mesenchymal stem cells. Mol Cell Endocrinol. 2007;271(1-2):1-17.

6. Takada I, Suzawa M, Matsumoto K, Kato S. Suppression of PPAR transactivation switches cell fate of bone marrow stem cells from adipocytes into osteoblasts. Ann N Y Acad Sci. 2007;1116:182-195.

7. Takahashi T. Overexpression of Runx2 and MKP-1 stimulates transdifferentiation of 3T3-L1 preadipocytes into bone-forming osteoblasts in vitro. Calcif Tissue Int. 2011;88(4):336-347.

8. Muruganandan S, Roman AA, Sinal CJ. Adipocyte differentiation of bone marrow-derived mesenchymal stem cells: cross talk with the osteoblastogenic program. Cell Mol Life Sci. 2009;66(2):236-253.
9. Jackson SM, Demer LL. Peroxisome proliferator-activated receptor activators modulate the osteoblastic maturation of MC3T3-E1 preosteoblasts. FEBS Lett. 2000;471(1):119-124.

10. Takano M, Otsuka F, Matsumoto $\mathrm{Y}$, Inagaki $\mathrm{K}$, Takeda $\mathrm{M}$, Nakamura $\mathrm{E}$, Tsukamoto N, Miyoshi T, Sada KE, Makino H. Peroxisome proliferator-activated receptor activity is involved in the osteoblastic differentiation regulated by bone morphogenetic proteins and tumor necrosis factor- $\mathrm{a}$. Mol Cell Endocrinol. 2012;348(1):224-232.

11. Akune T, Ohba S, Kamekura S, Yamaguchi M, Chung UI, Kubota N, Terauchi Y, Harada Y, Azuma Y, Nakamura K, Kadowaki T, Kawaguchi H. PPARgamma insufficiency enhances osteogenesis through osteoblast formation from bone marrow progenitors. J Clin Invest. 2004;113(6):846-855.

12. Lecka-Czernik B, Moerman EJ, Grant DF, Lehmann JM, Manolagas SC, Jilka RL. Divergent effects of selective peroxisome proliferator-activated receptor-gamma 2 ligands on adipocyte versus osteoblast differentiation. Endocrinology. 2002;143(6):2376-2384.

13. Rzonca SO, Suva LJ, Gaddy D, Montague DC, Lecka-Czernik B. Bone is a target for the antidiabetic compound rosiglitazone. Endocrinology. 2004;145(1):401-406.

14. Ali AA, Weinstein RS, Stewart SA, Parfitt AM, Manolagas SC, Jilka RL. Rosiglitazone causes bone loss in mice by suppressing osteoblast differentiation and bone formation. Endocrinology. 2005;146(3):1226-1235.

15. Yu WH, Li FG, Chen XY, Li JT, Wu YH, Huang LH, Wang Z, Li P, Wang T, Lahn BT, Xiang AP. PPARY suppression inhibits adipogenesis but does not promote osteogenesis of human mesenchymal stem cells. Int J Biochem Cell Biol. 2012;44(2):377-384.

16. Gregoire FM, Smas CM, Sul HS. Understanding adipocyte differentiation. Physiol Rev. 1998;78(3):783-809.

17. Grey A. Skeletal consequences of thiazolidinedione therapy. Osteoporos Int. 2008;19(2):129-137.

18. Liu LF, Shen WJ, Zhang ZH, Wang LJ, Kraemer FB. Adipocytes decrease Runx2 expression in osteoblastic cells: roles of PPARY and adiponectin. J Cell Physiol. 2010;225(3):837-845.

19. Delerive P, De Bosscher K, Besnard S, Vanden Berghe W, Peters JM, Gonzalez FJ, Fruchart JC, Tedgui A, Haegeman G, Staels B. Peroxisome proliferator-activated receptor alpha negatively regulates the vascular inflammatory gene response by negative cross-talk with transcription factors NF-kappaB and AP-1. J Biol Chem. 1999;274(45):32048-32054.

20. Okamoto H, Iwamoto T, Kotake S, Momohara S, Yamanaka H, Kamatani N. Inhibition of NF-kappaB signaling by fenofibrate, a peroxisome proliferator-activated receptor-alpha ligand, presents a therapeutic strategy for rheumatoid arthritis. Clin Exp Rheumatol. 2005;23(3):323-330.

21. Chan BY, Gartland A, Wilson PJ, Buckley KA, Dillon JP, Fraser WD, Gallagher JA. PPAR agonists modulate human osteoclast formation and activity in vitro. Bone. 2007:40(1):149-159.

22. Syversen U, Stunes AK, Gustafsson BI, Obrant KJ, Nordsletten L, Berge R, Thommesen L, Reseland JE. Different skeletal effects of the peroxisome proliferator activated receptor (PPAR)alpha agonist fenofibrate and the PPARgamma agonist pioglitazone. BMC Endocr Disord. 2009;9:10.

23. Stunes AK, Westbroek I, Gustafsson BI, Fossmark R, Waarsing JH, Eriksen EF, Petzold C, Reseland JE, Syversen U. The peroxisome proliferator-activated receptor (PPAR) alpha agonist fenofibrate maintains bone mass, while the PPAR gamma agonist pioglitazone exaggerates bone loss, in ovariectomized rats. BMC Endocr Disord. 2011;11:11.

24. Gimble JM, Robinson CE, Wu X, Kelly KA, Rodriguez BR, Kliewer SA, Lehmann JM, Morris DC. Peroxisome proliferator-activated receptor-gamma activation by thiazolidinediones induces adipogenesis in bone marrow stromal cells. Mol Pharmacol. 1996;50(5):1087-1094.

25. Kawaguchi H, Akune T, Yamaguchi M, Ohba S, Ogata N, Chung UI, Kubota N, Terauchi Y, Kadowaki T, Nakamura K. Distinct effects of PPARgamma insufficiency on bone marrow cells, osteoblasts, and osteoclastic cells. J Bone Miner Metab. 2005;23(4):275-279.

26. He W, Barak Y, Hevener A, Olson P, Liao D, Le J, Nelson M, Ong E, Olefsky JM, Evans RM. Adipose-specific peroxisome proliferator-activated receptor gamma knockout causes insulin resistance in fat and liver but not in muscle. Proc Natl Acad Sci U S A. 2003;100(26):15712-15717.

27. Sheng H, Rui XF, Sheng CJ, Li WJ, Cheng XY, Jhummon NP, Yu YC, Qu S, Zhang G, Qin L. A novel semisynthetic molecule icaritin stimulates osteogenic differentiation and inhibits adipogenesis of mesenchymal stem cells. Int J Med Sci. 2013;10(6):782-789

28. Grey A, Bolland M, Gamble G, Wattie D, Horne A, Davidson J, Reid IR. The peroxisome-proliferatoractivated receptor-gamma agonist rosiglitazone decreases bone formation and bone mineral density in healthy postmenopausal women: a randomized, controlled trial. J Clin Endocrinol Metab. 2007;92(4):1305-1310

29. Kahn SE, Zinman B, Lachin JM, Haffner SM, Herman WH, Holman RR, Kravitz BG, Yu D, Heise MA, Aftring RP, Viberti G; Diabetes Outcome Progression Trial (ADOPT) Study Group. Rosiglitazone-associated fractures in type 2 diabetes: an Analysis from A Diabetes Outcome Progression Trial (ADOPT). Diabetes Care. 2008;31(5):845-851.

30. Gruntmanis U, Fordan S, Ghayee HK, Abdullah SM, See R, Ayers CR, McGuire DK. The peroxisome proliferator-activated receptor-gamma agonist rosiglitazone increases bone resorption in women with type 2 diabetes: a randomized, controlled trial. Calcif Tissue Int. 2010;86(5):343-349. 